\title{
Co-culture of mouse embryos with oviduct and uterine cells prepared from mice at different days of pseudopregnancy*
}

\author{
D. Sakkas† and A. O. Trounson \\ Centre for Early Human Development, Monash Medical Centre, 246 Clayton Road, Clayton, \\ Victoria 3168, Australia
}

\begin{abstract}
Summary. Oviduct and uterine cell cultures were prepared from mice at different days of pseudopregnancy and their effects on the development of 1-and 8-cell mouse embryos in co-culture were examined. One-cell mouse embryos in co-culture with oviduct cells from $20 \mathrm{~h}$ to $120 \mathrm{~h}$ after hCG had a mean ( \pm s.e.) cell number of $70 \cdot 1 \pm 3 \cdot 6$, significantly $(P<0.001)$ higher compared with those cultured in Whittingham's T6 medium supplemented with $5 \%$ fetal calf serum (T6 + 5\% FCS) $(30 \cdot 4 \pm 1 \cdot 6)$. Transfer of embryos, at $96 \mathrm{~h}$ after hCG, to synchronous pseudopregnant recipients showed that more embryos in oviduct co-culture formed fetuses than those cultured in T6 $+5 \%$ FCS. Co-culture of 1-cell embryos with uterine cells did not confer an advantage in cell numbers over T6 + 5\% FCS. However, more 8-cell embryos formed blastocyst outgrowths after $100 \mathrm{~h}$ in co-culture with uterine cells prepared from mice at Day 3 of pseudopregnancy than with uterine cultures prepared from mice at Day 1 of pseudopregnancy or oviduct cells. In addition, there was further improvement when the Day 3 uterine co-cultures were supplemented with 1 or $10 \mathrm{ng}$ progesterone $/ \mathrm{ml}$.

These results highlight the importance of the oviduct and uterine cells during the different stages of preimplantation embryo development.
\end{abstract}

Keywords: co-culture; cleavage rate; embryo; oviduct; uterus; mouse

\section{Introduction}

Preimplantation development of mouse embryos can take place in vitro in the absence of oviducal factors, many proteins and other substances in simple chemically defined media, but the rate of cleavage and development is significantly delayed when compared to that in vivo (Harlow \& Quinn, 1982; Sakkas et al., 1989a).

The culture of embryos in vitro removes the embryo from the maternal environment where it is bathed in an ever-changing milieu of fluid containing a range of proteins and ions specific to the reproductive fluid (Neider \& Macon, 1987; Leese, 1988). Techniques such as the co-culture of embryos with oviduct and uterine cells (Gandolfi \& Moor, 1987; Sakkas et al., 1989a, b; Lavranos \& Seamark, 1989; Eyestone \& First, 1989) or culture of embryos in oviduct organ explants (Whittingham, 1968; Minami et al., 1988; Krisher et al., 1989) mimic the maternal environment and improve in-vitro embryo development. Co-culture with oviduct cells has allowed sheep, cattle and goat embryos to develop through specific cell cycles which do not occur in chemically defined media (Gandolfi \& Moor, 1987; Eyestone \& First, 1989; Sakkas et al., 1989b). Lavranos \& Seamark (1989) have also shown that in the mouse a greater percentage of 8 -cell embryos developed to the blastocyst stage and formed outgrowths in a uterine co-culture system than in medium alone. In

* Reprint requests to A. O. Trounson.

tPresent address: Clinique et Policlinique de Sterilité, Hopital Cantonal, Université de Geneve, Geneve 1205, Switzerland. 
addition, we have previously reported that co-culture of 2-cell mouse embryos with a mouse oviducal cell suspension allows embryos to retain cleavage rates and viability comparable to those in vivo (Sakkas et al., 1989a).

The present study attempts to mimic the maternal environment of mouse embryos and improve the development of embryos in vitro.

\section{Materials and Methods}

Collection of embryos. Female $\mathrm{F} 1(\mathrm{C} 57 \mathrm{BL} / 6 \mathrm{~J} \times \mathrm{CBA} / \mathrm{H})$ mice, 3-4 weeks of age, were injected at 16:00 h with $5 \mathrm{i} . \mathrm{u}$. PMSG (Intervet, Sydney, Australia). After $48 \mathrm{~h}$ mice were injected with 5 i.u. hCG (Intervet) and placed individually with a male of proven fertility. One-cell embryos were recovered $20-22 \mathrm{~h}$ after hCG by tearing the wall of the oviducts with fine forceps and allowing the embryos to be dispersed into M2 medium (Quinn et al., 1982) containing hyaluronidase (40 i.u./ml) (Sigma Pharmaceuticals, Clayton, Victoria, Australia) to remove the cumulus cells. Embryos at the 8 -cell stage were recovered by flushing the oviduct and uterus at $68 \mathrm{~h}$ after hCG with M2 medium. After collection, embryos were pooled and then randomly allocated to the various culture media and co-culture groups.

Preparation of cell cultures. Cultures were prepared, under sterile conditions, from adult female F1 mice on Days 1 or 3 (Day 1 = the day of finding a copulatory plug) of pseudopregnancy. The oviducts or uterus were removed from a single mouse and minced into small cubes in a $35-\mathrm{mm}$ Petri dish. The tissue was then placed in $0.05 \%$ pronase (Protease IV: Sigma Pharmaceuticals) in Earle's 199 medium (Commonwealth Serum Laboratories (CSL), Melbourne, Australia) for $90 \mathrm{~min}$ at $37^{\circ} \mathrm{C}$ in an atmosphere of $5 \% \mathrm{CO}_{2}$ on a shaking stage. After protease digestion the tissue suspension was vigorously pipetted up and down and passed through a $120-\mu \mathrm{m}$ pore size sieve to remove the undigested tissue. The cell suspension was washed twice by suspending the cells in $5 \mathrm{ml}$ Earle's 199 medium $+10 \%$ fetal calf serum (FCS) (CSL), followed by centrifugation at $600 \mathrm{~g}$ and the supernatant discarded. Oviduct cell preparations were resuspended in $200 \mu \mathrm{l}$ Earle's 199 medium $+10 \%$ FCS while uterine cell preparations were resuspended in $800 \mu \mathrm{l}$ of the same medium. Cells were then placed in Linbro 96-well plates (Flow Laboratories, Melbourne, Australia) in $100 \mu$ laliquants. Tissue culture wells were pretreated with $0.1 \%$ pig skin gelatin (Sigma Pharmaceuticals) by layering the well bottom with the pig skin gelatin solution for $1 \mathrm{~h}$ at $4^{\circ} \mathrm{C}$ and then removing the excess solution before adding the cells.

Table 1. Composition of CSM medium

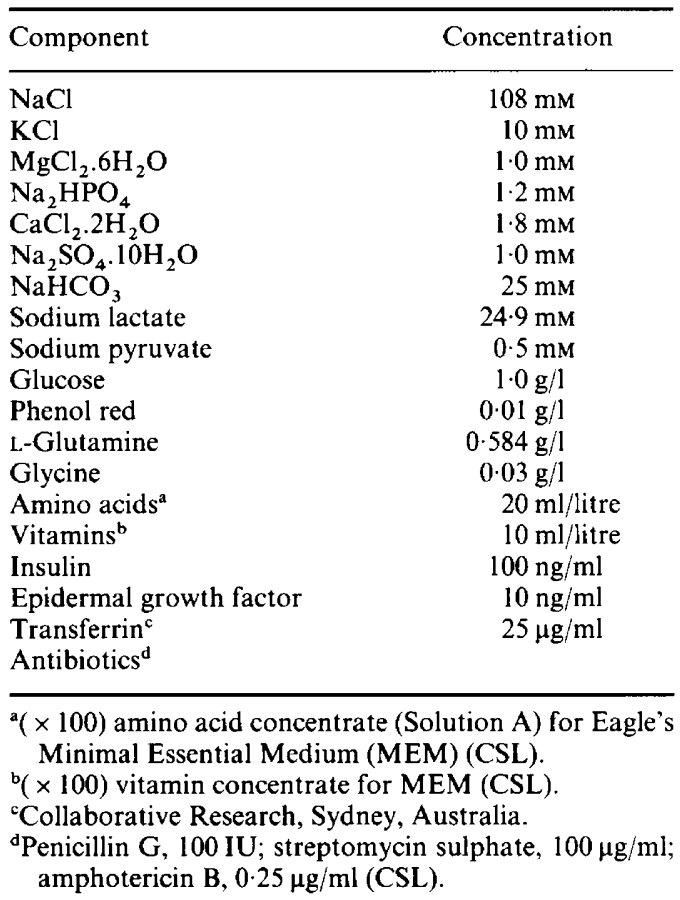


The following morning the cell monolayers were washed with Earle's salt solution (Flow Laboratories) to remove traces of FCS and $100 \mu \mathrm{l} \mathrm{CSM} \mathrm{(Table} \mathrm{1)} \mathrm{(Sakkas} \mathrm{\&} \mathrm{Trounson,} \mathrm{1989)} \mathrm{medium} \mathrm{were} \mathrm{placed} \mathrm{in} \mathrm{each} \mathrm{well} \mathrm{on} \mathrm{the}$ monolayers. Only cultures that had reached $60-80 \%$ confluence overnight were used.

Day 3 uterine cultures were also prepared with the addition of steroid supplements in the media. In this experiment I or $10 \mathrm{ng}$ oestradiol-17//ml (Sigma Pharmaceuticals) or 1 or $10 \mathrm{ng}$ progesterone $/ \mathrm{ml}$ (Sigma Pharmaceuticals) were added to the CSM medium. Wells were also prepared containing $100 \mu 1 \mathrm{~T} 6$ medium (Quinn et al., 1982) supplemented with $5 \%$ FCS. All culture media were overlaid with $100 \mu$ liquid paraffin oil (British Drug Houses Chemicals, Melbourne, Australia), unless otherwise stated, and maintained at $37^{\circ} \mathrm{C}$ in an atmosphere of $5 \% \mathrm{CO}_{2}$.

To investigate the composition of the oviduct and uterine cultures, both cell culture types were assessed for the presence of epithelial cell type, by using an anti-cytokeratin antibody. Cultures were prepared as above and, on the 2nd day of culture, fixed with methanol and air dried overnight. The following day the cultures were exposed to anticytokeratin (Bio-Clone, Sydney, Australia) and the binding of the antigen was detected by using the StreptavidinBiotin Amplified System (Histostain-SP kit for mouse primary antibody: Zymed Laboratories, San Fransisco, CA, USA).

Assessment of embryo development. The number of blastomeres per embryo and the morphological development of the 1-cell embryos was assessed at $28,40,52,64,76,96$ and $120 \mathrm{~h}$ after hCG. Up to and including the stage at $76 \mathrm{~h}$ after hCG, the cell numbers of embryos developing in vitro were assessed on an Olympus inverted microscope. At $96 \mathrm{~h}$ after hCG, half the embryos were removed from each treatment group and embryo cell numbers were determined by the cell spreading method described by Kola et al. (1986). At $120 \mathrm{~h}$ after hCG the remaining embryos were assessed for cell number. The development of 8-cell embryos was assessed by morphological criteria at 24-h intervals from 96 to $168 \mathrm{~h}$ after hCG on an inverted microscope and the number of embryos reaching specific stages was recorded. Three morphological stages were chosen to compare development; the expanded blastocyst stage ( $96 \mathrm{~h}$ after hCG), the hatched blastocyst stage when embryos had hatched from their zonae ( $144 \mathrm{~h}$ after hCG) and the attached stage when the embryos exhibit outgrowths of trophectodermal cells either on the culture well base or the uterine cells ( $168 \mathrm{~h}$ after hCG).

\section{Experiment 1}

Development of 1-cell mouse embryos in co-culture. One-cell mouse embryos were randomly allocated to 6 groups (10-20 embryos/group) to be cultured in T6 medium + 5\% FCS, CSM or in co-culture with Day-1 oviduct cells (DIOV), Day-3 oviduct cells (D3OV), Day-1 uterine cells (D1UT) or Day-3 uterine cells (D3UT) and their cell numbers were assessed. The experimental design is shown in Fig. 1(a).

Transfer of 1-cell embryos cultured in vitro and grown in vivo to synchronous Day-4 pseudopregnant recipients. Onecell mouse embryos were cuitured in T6 medium $+5 \%$ FCS or in co-culture with Day-1 oviduct cells. Embryos were removed from culture at $96 \mathrm{~h}$ after hCG and transferred to the uterine horns of synchronized Day-4 pseudopregnant recipients (Day $1=$ the day of finding a copulatory plug). Control embryos recovered from donors at $96 \mathrm{~h}$ after hCG were also transferred at the same times for comparisons of embryo viability in vivo and in vitro. Six embryos of a different treatment were transferred to each uterine horn. The reproductive tracts were examined on Day 15 after mating and the number, normality and weight of fetuses, and number of resorption sites were recorded.

Development of 1-cell mouse embryos in T6 medium + 5\% FCS and in Day-1 oviduct co-culture when transferred to Day-3 uterine co-culture. One-cell mouse embryos were cultured with Day-1 oviduct cells until $76 \mathrm{~h}$ after hCG and then transferred to co-culture over Day-3 uterine cells. The experimental design is shown in Fig. 1(b). This experiment was performed to assess whether mimicking the passsge of the embryo from the oviduct to the uterus, as occurs in vivo, improved cell numbers during prolonged culture. Embryos were examined for cell number at $96 \mathrm{~h}$ and $120 \mathrm{~h}$ after hCG and compared to those grown in Day-1 oviduct co-culture. A total of 30 embryos were examined at each timepoint.

\section{Experiment 2}

Development of 8-cell mouse embryos in co-culture. In this experiment the morphological development of 8-cell mouse embryos cultured with cells of the oviduct or uterus prepared from mice at Day 1 or 3 of pseudopregnancy was examined. The 8-cell mouse embryos were randomly allocated to 6 groups (T6 medium $+5 \%$ FCS, CSM or in coculture with cells from the oviduct or uterus of Day- 1 or Day-3 pseudopregnant mice) and their morphological development assessed. The experimental design is shown in Fig. 1(c). Between 100 and 110 embryos were assessed in each treatment group.

Development of 8-cell embryos on Day-3 uterine co-cultures supplemented with oestradiol and progesterone. To examine the effect of supplementing the culture medium with oestradiol-17 $\beta$ or progesterone, morphological development of 8-cell embryos was assessed in CSM medium alone or in co-culture with Day-3 uterine cells, supplemented with oestradiol- $17 \beta, 1$ or $10 \mathrm{ng} / \mathrm{ml}$, or progesterone, 1 or $10 \mathrm{ng} / \mathrm{ml}$. In this experiment the culture medium was not overlaid with oil. 
(a)

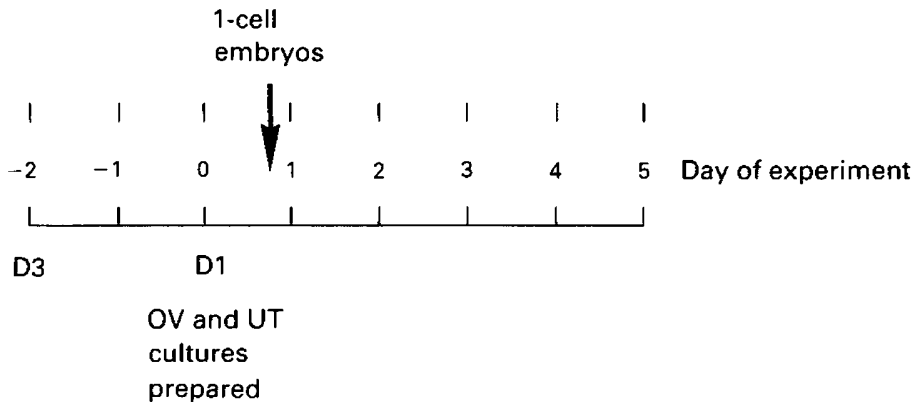

(b)

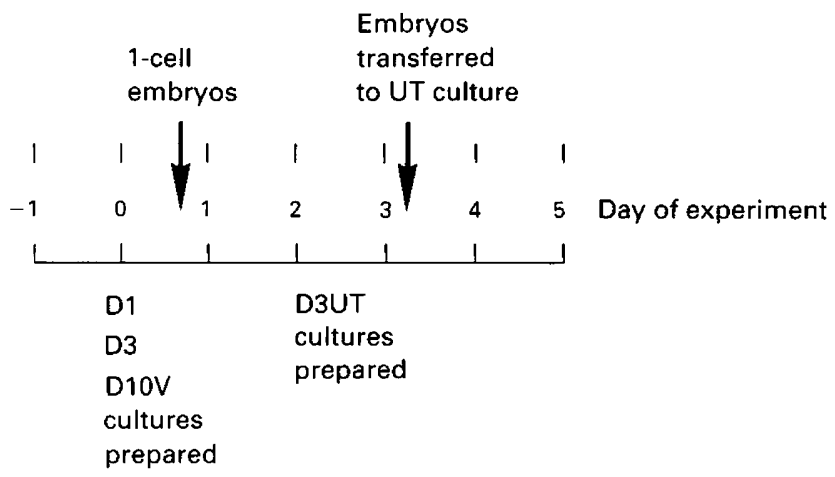

(c)

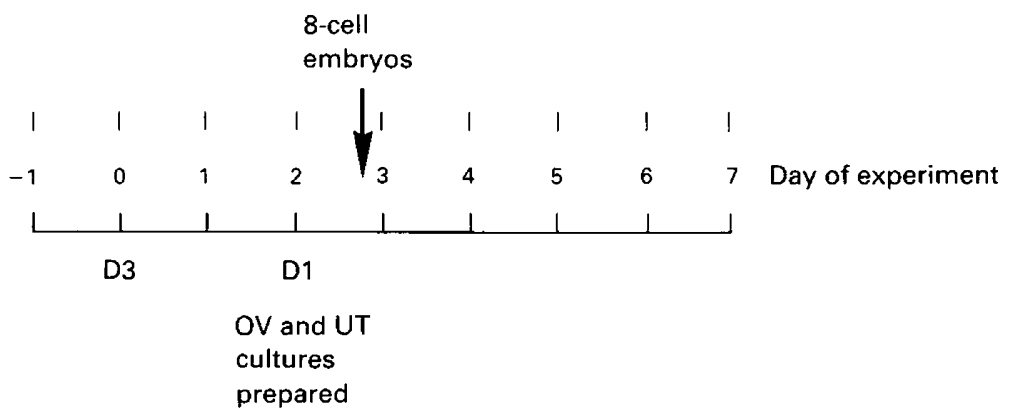

Fig. 1. The experimental schedule for provision of Day 1 (D1) and Day 3 (D3) pseudopregnant females, preparation of oviduct (OV) and uterine (UT) cultures and culture of embryos for (a) the culture of 1-cell embryos, (b) the transfer of embryos cultured on oviduct cells to uterine cells and (c) the culture of 8-cell embryos. Day 0 is the time of hCG injection.

\section{Statistical analyses}

In Exp. 1, within-group treatment effects and between treatment differences were assessed by analysis of variance. The fetal weights of embryos recovered after transfer were analysed by Student's $t$ test and the number of implantations and fetuses recovered after transfer were analysed by $\chi^{2}$ tests. Results obtained in Exp. 2 for the number of embryos at the different morphological stages were analysed by $\chi^{2}$ tests. 


\section{Results}

\section{Assessment of cell cultures}

Oviduct monolayer cultures contained both stromal and epithelial cell types. The latter were easily distinguished from the former as they had cilia, which continued beating for at least 4 days in culture, or formed quite distinct vesicular sacs at the apical borders of the cells. Uterine cultures underwent a change in appearance after 2-3 days in culture, forming clusters of smaller more rounded cells layered on top of each other. Oviduct and uterine cultures, stained with anticytokeratin, both displayed large groups of epithelial cells throughout the cultures.

\section{Experiment 1}

Co-culture of 1-cell embryos. At $40 \mathrm{~h}$ after hCG, all embryos in the in-vitro treatments had reached the 2-cell stage, but by $52 \mathrm{~h}$ after hCG embryos in vitro remained at the 2-cell stage while those in vivo had nearly all cleaved to the 4-cell stage. By $64 \mathrm{~h}$ after hCG, the Day-1 and Day-3 oviduct co-cultures had significantly $(P<0.05)$ higher mean $( \pm$ s.e.) cell numbers $(3.82 \pm 0.05$ and $3.87 \pm 0.05$, respectively) than did embryos cultured in T6 $+5 \%$ FCS $(3.42 \pm 0.07)$. The rates of development obtained in CSM alone or uterine co-culture were not significantly different from those in $\mathrm{T} 6+5 \% \mathrm{FCS}$. The pattern present at $64 \mathrm{~h}$ after hCG also existed at the later stages.

At $96 \mathrm{~h}$ after hCG, embryos developing in co-culture with Day-1 or Day-3 oviduct cells were retarded by one cleavage cycle compared with those in vivo $(62 \cdot 4 \pm 3 \cdot 1)$, while all other groups were nearly two cell cycles behind (Table 2). The difference between oviduct co-culture and the other invitro treatments remained at $120 \mathrm{~h}$ after hCG (Table 2). Comparison of between-day variation in cell numbers of the different treatments was not significant.

Table 2. Mean cell number ( \pm s.e.) of embryos grown from the 1-cell stage to the $96 \mathrm{~h}$ and $120 \mathrm{~h}$ after hCG stage in T6 $+5 \%$ FCS, CSM medium and in co-culture with Day-1 and Day-3 oviduct cells and Day-1 and Day-3 uterine cells using CSM medium alone

\begin{tabular}{|c|c|c|c|c|}
\hline \multirow[b]{2}{*}{$\begin{array}{l}\text { Treatment and } \\
\text { culture medium }\end{array}$} & \multicolumn{2}{|c|}{$96 \mathrm{~h}$ after $\mathrm{hCG}$} & \multicolumn{2}{|c|}{$120 \mathrm{~h}$ after $\mathrm{hCG}$} \\
\hline & $\begin{array}{l}\text { No. of } \\
\text { embryos }\end{array}$ & $\begin{array}{c}\text { Mean cell } \\
\text { no. }( \pm \text { s.e. })\end{array}$ & $\begin{array}{c}\text { No. of } \\
\text { embryos }\end{array}$ & $\begin{array}{c}\text { Mean cell } \\
\text { no. }( \pm \text { s.e. })\end{array}$ \\
\hline $\mathrm{T} 6+5 \% \mathrm{FCS}$ & 40 & $14 \cdot 3 \pm 0 \cdot 6$ & 44 & $30 \cdot 4 \pm 1 \cdot 6$ \\
\hline CSM & 40 & $11 \cdot 1 \pm 0 \cdot 6^{*}$ & 45 & $20 \cdot 9 \pm 1 \cdot 5^{* *}$ \\
\hline Day I oviduct & 43 & $31 \cdot 3 \pm 1 \cdot 1^{* *}$ & 53 & $70 \cdot 1 \pm 3 \cdot 6^{* *}$ \\
\hline Day 3 oviduct & 42 & $28 \cdot 7 \pm 0.9^{* *}$ & 45 & $67 \cdot 1 \pm 3 \cdot 8^{* *}$ \\
\hline Day I uterine & 39 & $15 \cdot 6 \pm 0.7$ & 42 & $22 \cdot 5 \pm 1 \cdot 6^{*}$ \\
\hline Day 3 uterine & 44 & $14 \cdot 7 \pm 0 \cdot 5$ & 42 & $26 \cdot 1 \pm 1 \cdot 8$ \\
\hline In vivo & 42 & $62 \cdot 4 \pm 3 \cdot 1^{* *}$ & - & - \\
\hline
\end{tabular}

${ }^{*} P<0.01$ compared with $\mathrm{T} 6+5 \%$ FCS value.

${ }^{* *} P<0.001$ compared with T6 $+5 \%$ FCS value.

Transferred embryos. The number of fetuses and their mean weight was significantly better $(P<0.001)$ for embryos transferred to synchronous recipients after development in vivo than embryos cultured in vitro (Table 3 ). However, of the in-vitro treatments, the mean number $\left(\chi^{2}=\right.$ $4.8, P<0.05)$ and fetal weights $(t=5.02, P<0.01)$ of embryos transferred after co-culture with oviduct cells were significantly better than for embryos cultured with T6 $+5 \%$ FCS (Table 3 ).

Embryos transferred to uterine co-culture. Embryos transferred to Day-3 uterine co-culture at $76 \mathrm{~h}$ after hCG from Day-1 oviduct co-culture had a mean cell number ( \pm s.e.) of $23.1 \pm 0.8$ at $96 \mathrm{~h}$ after hCG and $65.9 \pm 3.0$ at $120 \mathrm{~h}$ after hCG. There was no significant improvement compared to 
Table 3. Results of the transfer of embryos cultured in $\mathrm{T} 6+5 \% \mathrm{FCS}$, Day-1 oviduct co-culture and grown in vivo

\begin{tabular}{lccc}
\hline & \multicolumn{2}{c}{ Embryos cultured in vitro } & \\
\cline { 2 - 3 } Factor & $\begin{array}{c}\text { T6 }+5 \% \text { FCS } \\
\text { medium }\end{array}$ & $\begin{array}{c}\text { Day-1 oviduct } \\
\text { co-culture }\end{array}$ & $\begin{array}{c}\text { Embryos grown } \\
\text { in vivo }\end{array}$ \\
\hline $\begin{array}{l}\text { No. of embryos } \\
\text { transferred }\end{array}$ & 48 & 48 & \\
$\begin{array}{l}\text { No. of implantations } \\
\text { No. of resorptions }\end{array}$ & $11(23 \%)^{*}$ & $16(33 \%)^{*}$ & $27(75 \%)$ \\
$\begin{array}{l}\text { No. of fetuses } \\
\text { Mean } \pm \text { s.e. fetal }\end{array}$ & $4(8 \%)^{* \dagger}$ & 4 & 4 \\
weight (g) & $0 \cdot 123 \pm 0.008^{*} \dagger$ & $0 \cdot 169 \pm 0.005^{*}$ & $0.217 \pm 0.005$ \\
\hline
\end{tabular}

${ }^{*} P<0.001$ compared with value in vivo.

$\dagger P<0.05$ compared with Day-1 oviduct co-culture.

embryos cultured in co-culture with oviduct cells only $(26 \cdot 1 \pm 1 \cdot 3$ at $96 \mathrm{~h}$ after hCG and $73 \cdot 0 \pm 4 \cdot 1$ at $120 \mathrm{~h}$ after $\mathrm{hCG}$ ).

\section{Experiment 2}

Co-culture of 8 -cell embryos. The assessment of the morphological development of compacting 8-cell embryos in co-culture showed that by $96 \mathrm{~h}$ after hCG more embryos had formed expanded blastocysts when cultured with uterine cells than in T6 +5\% FCS (Fig. 2). However, at $144 \mathrm{~h}$ after hCG, significantly $(P<0.01)$ more embryos cultured in T6 $+5 \%$ FCS had hatched from the zona pellucida than in uterine co-culture (Fig. 2).

At $168 \mathrm{~h}$ after hCG significantly more of the embryos were attaching and forming trophoblastic outgrowths in the Day-3 uterine co-cultures than in all other in-vitro culture groups (Fig. 2).

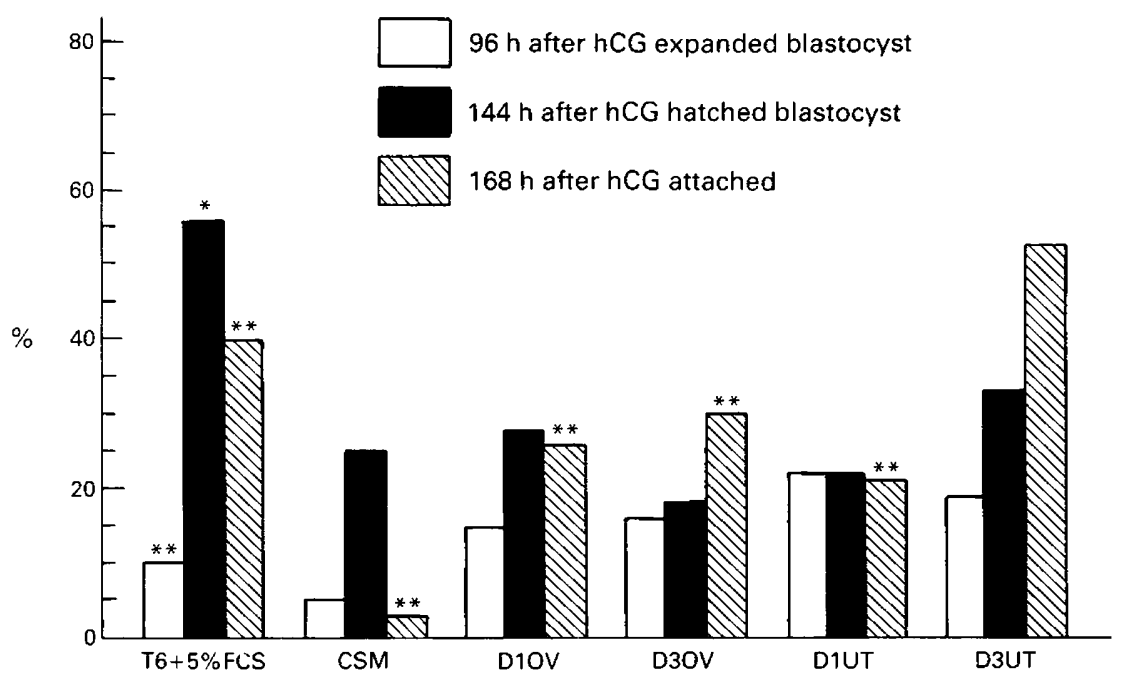

Fig. 2. The stage of development of 8-cell mouse embryos cultured in T6 +5\% FCS, CSM medium alone and in co-culture with Day 1 oviduct cells (D1OV), Day 3 oviduct cells (D3OV), Day 1 uterine cells (D1UT) and Day 3 uterine cells (D3UT) at 96, 144 and $168 \mathrm{~h}$ after hCG. ${ }^{*} P<0.05$ compared with Day-3 uterine value. ${ }^{* *} P<0.01$ compared with Day-3 uterine value. 
Co-culture of 8-cell embryos in the presence of steroids. Supplementation of CSM medium alone with $1 \mathrm{ng}$ oestradiol- $17 \beta / \mathrm{ml}$ significantly improved $(P<0.05)$ the hatching of the blastocyst from the zona compared to CSM media with other concentrations of oestradiol-17 $\beta$ or progesterone. In all other cases addition of steroids to medium had no beneficial effect on blastocyst development (Table 4).

Table 4. Effect of inclusion of oestradiol $\left(\mathrm{E}_{2}\right)$ or progesterone $\left(\mathrm{P}_{4}\right)$ in CSM medium on development of 8-cell mouse embryos in co-culture with (D3UT) or without (-) Day-3 uterine cells

\begin{tabular}{|c|c|c|c|c|c|c|c|c|c|c|c|}
\hline \multirow{2}{*}{$\begin{array}{l}\text { Time }(h) \\
\text { after } \\
\text { hCG }\end{array}$} & \multirow{2}{*}{$\begin{array}{l}\text { Developmental } \\
\text { stage }\end{array}$} & \multicolumn{2}{|c|}{ CSM } & \multicolumn{2}{|c|}{$\begin{array}{c}\mathrm{E}_{2} \\
(1 \mathrm{ng} / \mathrm{ml})\end{array}$} & \multicolumn{2}{|c|}{$\begin{array}{c}\mathrm{E}_{2} \\
(10 \mathrm{ng} / \mathrm{ml})\end{array}$} & \multicolumn{2}{|c|}{$\begin{array}{c}\mathrm{P}_{4} \\
(1 \mathrm{ng} / \mathrm{ml})\end{array}$} & \multicolumn{2}{|c|}{$\begin{array}{c}\mathrm{P}_{4} \\
(10 \mathrm{ng} / \mathrm{ml})\end{array}$} \\
\hline & & - & D3UT & - & D3UT & - & D3UT & - & D3UT & - & D3UT \\
\hline $\begin{array}{l}68 \\
96\end{array}$ & Morulae (n) & 99 & 102 & 95 & 105 & 96 & 104 & 97 & 105 & 102 & 105 \\
\hline 140 & $\begin{array}{l}\text { blastocyst }(\%) \\
\text { Hatched }\end{array}$ & $10^{* *}$ & 26 & $10^{* *}$ & $7^{* *}$ & $10^{* *}$ & $15^{* *}$ & $6^{* *}$ & $37^{*}$ & $13^{* *}$ & $37^{* *}$ \\
\hline & bastocyst (\%) & $14^{* *}$ & 33 & 30 & 22 & $6^{* *}$ & $9^{* *}$ & $8^{* *}$ & 35 & $16^{* *}$ & 32 \\
\hline 168 & Attached $(\%)$ & $5^{* *}$ & 46 & $3^{* *}$ & $15^{* *}$ & $0^{* *}$ & $31^{* *}$ & $8^{* *}$ & $70^{* *}$ & $11^{* *}$ & $65^{* *}$ \\
\hline
\end{tabular}

${ }^{*} P<0.05$ compared with D3UT CSM value.

** $P<0.01$ compared with D3UT CSM value.

Further improvement was achieved in co-culture of 8-cell embryos with Day-3 uterine cells when progesterone was included in the medium. At $96 \mathrm{~h}$ after hCG significantly more embryos had formed expanded blastocysts in co-culture with Day-3 uterine cells with $1 \mathrm{ng}\left(\chi^{2}=3.80 ; P<0.05\right)$ or $10 \mathrm{ng}\left(\chi^{2}=3.90 ; P<0.05\right)$ progesterone/ml in the medium compared to no steroid supplementation (Table 4). Supplementing the co-culture media with oestradiol-17 $\beta$ decreased the percentage of embryos forming expanded blastocysts (Table 4).

The improved rate of attachment observed with Day-3 uterine co-culture was significantly increased when $1\left(\chi^{2}=80 ; P<0.005\right)$ or $10 \mathrm{ng}$ progesterone $/ \mathrm{ml}\left(\chi^{2}=5.90 ; P<0.02\right)$ was added to the culture medium (Table 4 ).

\section{Discussion}

Development of 1-cell mouse embryos in co-culture with oviduct cells maintained cleavage rates within one cleavage cycle of embryos grown in vivo up to $96 \mathrm{~h}$ after hCG. However, embryos cultured in T6 $+5 \%$ FCS were retarded by nearly 2 cell cycles compared to in vivo. The benefit observed in embryo cell numbers using oviduct co-culture also compares favourably with that obtained by Papaioannou \& Ebert (1986) when 1-cell mouse embryos were transferred to the oviducts of immature mice $(33.2 \pm 2 \cdot 7)$ and pseudopregnant females $(40.5 \pm 3 \cdot 7)$ for 3 days and compared to embryos developing in vivo $(54 \cdot 0 \pm 3 \cdot 4)$.

The importance of maintaining in-vivo cleavage rates was emphasized by the transfer of embryos developing from the 1-cell stage for $74 \mathrm{~h}$ in either co-culture with oviduct cells or T6 $+5 \%$ FCS. Transfer of embryos to a synchronous environment is a more exacting test on the level of retardation experienced by the embryo in vitro. In the present study more implanting embryos developed to fetuses after co-culture with oviduct cells than in T6 $+5 \%$ FCS. A further increase in embryo cell numbers was not obtained in our attempt to mimic the passage of the embryo, by transferring embryos into a uterine co-culture system after co-culture with oviduct cells. This may be due to the majority of embryos being retarded to such an extent that they have lost synchrony with the uterine culture. 
In all in-vitro treatments the longest period of delay occurred during the 2- to 4-cell stage at which 12-16 h retardation was evident when compared to that in vivo. Since the inception of mouse embryo culture techniques the 2-cell stage has been shown to be unusually sensitive in vitro. In the mouse the 2-cell stage is particularly important, as embryonic genome activation occurs (Goddard \& Pratt, 1983). Several factors such as the ratio of lactate and pyruvate (Biggers, 1971; Whittingham, 1974) and glucose and glutamine levels (Chatot et al., 1989) have been reported to enhance or inhibit development during this stage. The inherent metabolic actions of the cells in a co-culture system may in fact operate by modifying the ratio of such factors or contribute specific factors that enhance embryo cleavage rates, particularly, for example the oviduct cells, because in the present study co-culture with uterine cells was not beneficial to 1-cell embryo cultures.

Several studies have shown that proteins present in the oviducal lumen bind to the embryo, but none of these proteins has been linked to a specific functional role for the development of the embryo (Shapiro et al., 1974; Gaunt, 1985; Leveille et al., 1987; Gandolfi et al., 1989). In the mouse, Kapur \& Johnson $(1985,1986)$ identified a protein of $M_{\mathrm{r}} 215000$ that was secreted by oviducal epithelial cells and selectively sequestered and retained in the perivitelline space of postovulatory oocytes and embryos. The uptake of gold-labelled insulin by receptor-mediated endocytosis has been shown to occur as early as the 8-cell stage (Heyner et al., 1989). Insulin, in this study, was also reported to be present in the oviducal fluid. Oviduct mitogenic factor (OMF), a protein isolated from the secretions of sheep oviducal cells, has also been reported to increase the $\left[{ }^{35} \mathrm{~S}\right]$ methionine incorporation by 1-cell sheep embryos by 2.5 times (Gandolfi et al., 1988). In several species, difficulty with the in-vitro culture of early stage embryos, as evidenced by blockage during culture, has been overcome by oviduct co-culture systems (Gandolfi \& Moor, 1987; Eyestone \& First, 1989; Sakkas et al., 1989b).

Although co-culture with oviduct cells enhanced embryo cell numbers, oviduct cultures prepared from mice on different days of pseudopregnancy did not differ in their ability to support the development of 1-cell embryos. The role of the oviduct during different stages of the oestrous cycle appears unclear. Several studies have shown an inhibitory influence of oestrous oviduct fluid on 1cell rabbit embryos (Kille \& Hamner, 1973) and on mouse embryos (Cline et al., 1977) developing to the blastocyst stage. In contrast, Whittingham (1968) showed that oviduct organ explants prepared from metoestrous I mice enhanced embryo development to the blastocyst stage. The lack of difference between oviduct cultures in the present study may be due to the isolation of cells in culture, which removes them from changes in hormone concentrations that they are usually exposed to. The effect of steroids on oviduct co-cultures is currently under investigation.

Unlike oviduct cultures, uterine cultures prepared from Day-1 or $\mathbf{- 3}$ pseudopregnant females differed in their ability to support development of 8-cell embryos. The increased rate of attachment on Day-3 uterine monolayers, compared with Day-1 uterine cells and oviduct cells, may indicate that they are more receptive to the implanting embryo. In addition, the improved rate of development of 8-cell embryos to the expanded blastocyst stage in co-culture with uterine cells indicates that uterine cells may produce specific factors that stimulate embryo development after compaction. Fischer (1987) has shown that supplementation with uterine flushings of culture medium significantly promoted cell proliferation of rabbit blastocysts as measured by $\left[{ }^{3} \mathrm{H}\right]$ thymidine incorporation.

Co-culture of compacting embryos with uterine cells was improved when progesterone was added to the medium. These results are in agreement with those of Lavranos \& Seamark (1989). The effect of oestradiol and progesterone on preimplantation mouse embryos cultured in medium alone has been studied by several workers, but their findings are contradictory (Whitten, 1957; Kirkpatrick, 1971). Roblero \& Izquierdo (1976) found no effect of progesterone on preimplantation mouse embryos when added to the embryo culture medium alone. However, when progesterone was added to BMOC-2 medium supplemented with $15 \%$ serum, embryo cleavage rates were enhanced, implying the presence of a progesterone carrier in the serum (Roblero \& Izquierdo, 
1976). If a carrier is present in the co-culture system it appears that the uterine cells may secrete a protein that serves this function.

The poor development of embryos during the extended cell cycle, when blockage is most likely to occur, and loss of developmental viability after compaction has been shown to be a major hurdle in development in several species (Gandolfi \& Moor, 1987; Sakkas et al., 1989b). The results reported in this study indicate a direct role for the oviduct and uterine cells during preimplantation embryo development, highlighting the importance of contributions from the reproductive tract during the different stages of preimplantation embryo development.

\section{We thank Marcela Potenza for technical assistance.}

\section{References}

Biggers, J.D. (1971) New observations on the nutrition of the mammalian oocyte and the preimplantation embryo. In The Biology of the Blastocyst, pp. 319-327. Ed. R. J. Blandau. University of Chicago Press, Chicago.

Chatot, C.L., Ziomek, C.A., Bavister, B.D., Lewis, J.L. \& Torres, I. (1989) An improved culture medium supports development of random-bred 1-cell mouse embryos in vitro. J. Reprod. Fert. 86, 679-688.

Cline, E.M., Randall, P.A, \& Oliphant, G. (1977) Hormone-mediated oviductal influence on mouse embryo development. Fert. Steril. 28, 766-771.

Eyestone, W.H. \& First, N.L (1989) Co-culture of early cattle embryos to the blastocyst stage with oviducal tissue or in conditioned medium. J. Reprod. Fert. 85, $715-720$.

Fischer, B. (1987) Development retardation in cultured preimplantation rabbit embryos. J. Reprod. Fert. 79, $115-123$.

Gandolfi, F. \& Moor, R.M. (1987) Stimulation of early embryonic development in the sheep by co-culture with oviduct epithelial cells. J. Reprod. Fert. 81, $23-28$.

Gandolfi, F., Tiziana, A.L. \& Blakely, D.M. (1988) Detection of an oviduct mitogenic factor in the sheep. J. Reprod. Fert., Abstr. Series 1, 63, Abstr. 115.

Gandolfi, F., Brevini, T.A.L., Richardson, L., Brown, C.R. \& Moor, R.M. (1989) Characterization of proteins secreted by sheep oviduct epithelial cells and their function in embryonic development. Development 106, 303-312.

Gaunt, S.J. (1985) In vivo and in vitro cultured mouse preimplantation embryos differ in their display of a teratocarcinoma cell surface antigen: possible binding of an oviduct factor. J. Embryol. exp. Morphol. $88,55-69$.

Goddard, M.J. \& Pratt, H.M. (1983) Control of events during early cleavage of the mouse embryo: an analysis of the " 2 cell block". J. Embryol. exp. Morphol. 73, 111-133.

Harlow, G.M. \& Quinn, P. (1982) Development of preimplantation mouse embryos in vivo and in vitro. Aust. J. biol. Sci. 35, 187-193.

Heyner, S., Rao, L.V., Jarret, L. \& Smith, R.M. (1989) Preimplantation mouse embryos internalize maternal insulin via receptor-mediated endocytosis: Pattern of uptake and functional correlations. Devl Biol. 134, $48-58$.
Kapur, R.P. \& Johnson, L.V. (1985) An oviductal fluid glycoprotein associated with ovulated mouse ova and early embryos. Devl Biol. 112, 89-93.

Kapur, R.P. \& Johnson, L.V. (1986) Selective sequestration of an oviductal fluid glycoprotein in the perivitelline space of mouse oocytes and embryos. J. exp. Zool. 238, 249-260.

Kille, J.W. \& Hamner, C.E. (1973) The influence of oviducal fluid on the development of one-cell rabbit embryos in vitro. J. Reprod. Fert. 35, 415-423.

Kirkpatrick, J.F. (1971) Differential sensitivity of preimplantation mouse embryos in vitro to oestradiol and progesterone. J. Reprod. Fert. 27, 283-285.

Kola, I., Folb, P.I. \& Parker, M.I. (1986) Maternal administration of cyclophosphamide induces chromosomal aberrations and inhibits cell number, histone synthesis and DNA synthesis in preimplantation mouse embryos. Teratogen. Carcinogen. Mutagen. 6, 115-127.

Krisher, R.L., Petters, R.M., Johnson, B.H. \& Archibong, A.E. (1989) Development of porcine embryos from the one-cell stage to blastocyst in mouse oviducts maintained in organ culture. J. exp. Zool. 249, 235-239.

Lavranos, T.C. \& Seamark, R.F. (1989) Addition of steroids to embryo-uterine monolayer co-culture enhances embryo survival and implantation in vitro. Reprod. Fertil. Dev. 1, 41-46.

Leese, H.J. (1988) The formation and function of oviduct fluid. J. Reprod. Fert. 82, 843-856.

Leveille, M., Roberts, K.D., Chevalier, S., Chapdelaine, A. \& Bleau, G. (1987) Uptake of an oviductal antigen by the hamster zona pellucida. Biol. Reprod. 36, 227-238.

Minami, N., Bavister, B.D. \& Iritani, A. (1988) Development of hamster two-cell embryos in the isolated mouse oviduct in organ culture system. Gamete Res. 19, 235240.

Neider, G.L. \& Macon, G.R. (1987) Uterine and oviducal protein secretion during early pregnancy in the mouse. J. Reprod. Fert. 81, 287-294.

Papaioannou, V.E. \& Ebert, K.M. (1986) Development of fertilized embryos transferred to the oviducts of immature mice. J. Reprod. Fert. 6, 603-608.

Quinn, P., Barros, C. \& Whittingham, D.G. (1982) Preservation of hamster oocytes to assay the fertilizing capacity of human spermatozoa. J. Reprod. Fert. 66, 161-168. 
Roblero, L. \& Izquierdo, L. (1976) Effect of progesterone on the cleavage rate of mouse embryos in vitro. $J$. Reprod. Fert. 46, 475-476.

Sakkas, D. \& Trounson, A.O. (1989) Formulation of a complex serum free medium (CSM) that supports improved development of mouse embryos. Proc. $21 \mathrm{st}$ Ann. Mtg Aust. Soc. Reprod. Biol., Melbourne, p. 38 Abstr.

Sakkas, D., Trounson, A.O. \& Kola, I. (1989a) In vivo cleavage rates and viability obtained for early cleavage mouse embryos in co-culture with oviduct cells. Reprod. Fertil. Dev. 1, 127-136.

Sakkas, D., Batt, P.A. \& Camern, A.W.N. (1989b) Development of preimplantation goat (Capra hircus) embryos in vivo and in vitro. J. Reprod. Fert. 87, $359-365$.
Shapiro, S.S., Brown, N.E. \& Yard, A.S. (1974) Isolation of an acidic glycoprotein from rabbit oviducal fiuid and its association with the egg coating. J. Reprod. Fert. 40, 281-290.

Whitten, W.K. (1957) The effect of progesterone on the development of mouse eggs in vitro. J. Endocr. 16, $80-85$.

Whittingham, D.G. (1968) Development of zygotes in cultured mouse oviducts. I. The effect of varying oviductal conditions. J. exp. Zool. 169, 399-406.

Whittingham, D.G. (1974) Fertilisation, early development and storage of mammalian ova in vitro. In Early Development of Mammals, pp. 1-24. Eds M. Balls \& A. E. Wild. Cambridge University Press.

Received 6 November 1989 